\title{
Synthesis, Spectral, Anticancer Studies on Cu (II) Complex of 2,4,5- Triphenyl-1H-Imidazole
}

\author{
Fahimah Martak, Iin Candrawati, Ayu Widyasari \\ Chemistry Department, Faculty of Mathematic and Natural Science, Institut Teknologi Sepuluh Nopember \\ Surabaya \\ E-mail:fahimahm@chem.its.ac.id
}

Received: September 2016; Revised: October 2016; Accepted: November 2016; Available Online: December 2016

\begin{abstract}
Schiff bases of 2,4,5-triphenyl-1H-imidazole ligand and $\mathrm{Cu}$ (II) complex has been synthesized and characterized by ${ }^{1} \mathrm{H}$ and ${ }^{13} \mathrm{C}$ NMR, elemental analyses, molar conductance, thermal analysis (TGA), magnetic moment measurement, IR and UV-Vis. On the basis spectral studied and analytical data, it is evident that the Schiff base acts as monodentat ligand coordinating via nitrogen atom. The result showed that $\mathrm{Cu}$ (II) complex has octahedral geometry. The studied complex was tested for anticancer activity. The anticancer activity of $\mathrm{Cu}$ (II) complex is evaluated against liver Carninoma (HEPG2) cell lines. These compounds exhibit a moderate and weak activity against HCT 116 cell line with $\mathrm{IC}_{50} 19.8 \mu \mathrm{M}$.
\end{abstract}

Keywords: Schiff bases, anticancer, imidazole, octahedral geometry

DOI: http://dx.doi.org/10.15408/jkv.v0i0.3328

\section{INTRODUCTION}

Imidazole derivatives have been shown to exhibit interesting biological activities, including anti-allergy, anti-tumor, anti-inflammatory, anti-bacterial, and analgesic (Shelke et al., 2009; Wang et al., 2001; Mohammadi et al., 2012; Joshi et al., 2010; Ucucu et al., 2001). Hence, imidazole plays an important role in biochemistry, medical science, non linear optical materials and so on. Researches on complex compounds as anticancer have been developed until now many studies of new anticancer drugs made of metal that have been reported. Metal attached directly to an organic compound is called organomettalic compounds. Organomettalic complex can be classified based on cytotoxic activity against cancer cells by looking at the chemical-physical processes that enable the interactions toward biological targets (Sadler, 1991).

In some studies, the imidazole derivatives are widely used as ligands in the formation of complex compounds. Imidazole derivatives provide good antimicrobial activity. One of the examples is the formation of complex with the 2-(4-thiazolyl)- $1 \mathrm{H}$ benzimidazole and benzimidazole ligand. 2-(4thiazolyl)-1 $H$-benzimidazole compound has antimicrobial and antifungal activity higher than benzimidazole (Rahmapreet et al., 2011). It happened because 2-(4-thiazolyl)-1Hbenzimidazole has more aromatic substituents. Imidazole derivatives with the substitution of fluorine, propylene, and aromatic tetrahydroquinoline can improve stability, bioactivity and biological activity. 2,4,5triphenyl- $1 H$-imidazole has a structure that allows it to be a bridging ligand so that the possibility to form complex polymers are also quite high (Walia, 2011). The polymer complexs have very good stability. 2,4,5triphenyl- $1 \mathrm{H}$-imidazoles can be used as a corrosion inhibitor as reported (Wahyuningrum, 2008). However, only few studies discuss its biological activity and toxicity.

Therefore, the present work aims to synthesize Schiff base ligand 2,4,5-Triphenyl$1 H$-Imidazole and its complex with $\mathrm{Cu}(\mathrm{II})$ ion. 
The complex has been characterized by several tools of analyses such as ${ }^{1} \mathrm{H}$ and ${ }^{13} \mathrm{H}$ NMR, elemental analyses, molar conductance, thermal analysis (TGA), magnetic moment measurement, IR and UV-Vis spectra. Also, anticancer activity of the synthesized compound has been studied.

\section{MATERIAL AND METHODE}

\section{Materials}

All compounds used in the present study were of pure grade available from Merck. The solvents used for the spectral studies were spectroscopic grade from Aldrich.

\section{Instrumentations}

The elemental microanalyses of the solid compound was performed at the micro analytical center, ${ }^{1} \mathrm{H}$-NMR and ${ }^{13} \mathrm{C}-\mathrm{NMR}$ Jeol 500, University Kebangsaan Malaysia using Perkin Elmer 2400 CHN Elemental analyzer, Metal content was estimated using Atomic Absorption Spectroscpy (AAS) ZEEnit 700, Molar conductivities in DMF $\left(10^{-3} \mathrm{M}\right)$ at room temperature $\left(27{ }^{\circ} \mathrm{C}\right)$ were measured using Mettler Toledo, The infrared spectra were recorded using 8400S Shimadzu FTIR spectrophotometer within the range 4000-400 $\mathrm{cm}^{-1}$ as $\mathrm{KBr}$ discs. The electronic absorption were recorded using a genesys $10 \mathrm{~S} \mathrm{UV}-\mathrm{V}$ is spectrophotometer. The room temperature magnetic susceptibility of the solid samples was measured using magnetic susceptibility balance (MSB) Sherwood Scientific LTD 1 employing the Gouys method. The thermogravimetric analysis (TGA) of the solid samples was performed within the temperature range $25-500{ }^{\circ} \mathrm{C}$ using the STAR SW 10.00 thermogravimetric analyzer with heating rate $\left(10^{\circ} \mathrm{C} / \mathrm{min}\right)$ under nitrogen atmosfir.

\section{Synthesis of 2,4,5-triphenyl-1 $\mathrm{H}$-imidazoles Ligand}

The Schiff base ligand (Fig. 1) was prepared by the reflux of benzyl $(0.82 \mathrm{~g}, 3.8$ mmol), (1.52 g, $19.7 \mathrm{mmol})$ ammonium acetate and $0.3 \mathrm{~mL}$ benzaldehyde in $30 \mathrm{~mL}$ acetate acid. A mixture of them was refluxed for $2.5 \mathrm{~h}$. The reaction mixture was then poured onto ice water. The product which separated immediately was filtered off, washed several times with cold water and finally dried in a vacuum desiccators over anhydrous calcium chloride.

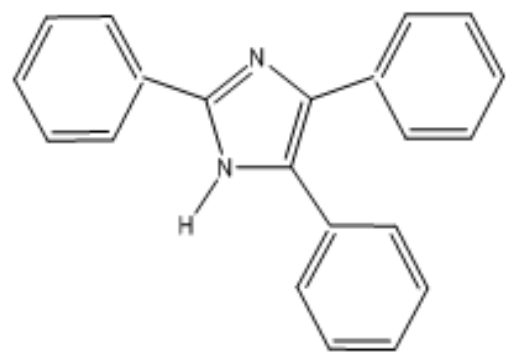

Figure 1. The structure of Schiff base 2,4,5triphenyl- $1 H$-imidazoles ligand

Synthesis of Complex $\mathrm{Cu}(\mathrm{II})$ with 2,4,5triphenyl-1H-imidazoles Ligand

To a solution of ligand $(0.29 \mathrm{~g}, 1$ $\mathrm{mmol})$ in $20 \mathrm{ml}$ methanol, a methanol $(20 \mathrm{ml})$ of the hydrated $\mathrm{Cu}$ (II) nitrate (0.12 gram, 0,5 mmol $\left.\mathrm{Cu}\left(\mathrm{NO}_{3}\right)_{2} \cdot 3 \mathrm{H}_{2} \mathrm{O}\right)$ was added slowly with constant stirring. The reaction mixture was heated to reflux for $24 \mathrm{~h}$. The resulting mixture was filtered off and then left to evaporate in a beaker in air at ambient temperature. Green crystal were formed within several days.

\section{RESULTS AND DISCUSSION}

\section{Elemental Analysis and Atomic Absorption Spectrophotometer Analysis}

Levels of metal ions $\mathrm{Cu}$ (II) complex synthesis product is determined by atomic absorption spectroscopy instruments. Snippets can be measured by the instrument SSA tangible solution. The complex is not soluble in distilled water. The compound was destructed in $\mathrm{HNO}_{3}$ solution, then added with aquademin.

Table 1. Result of elemental analysis complex $\mathrm{Cu}$ (II) with 2,4,5-triphenyl- $1 H$-imidazoles

\begin{tabular}{|c|c|c|c|c|c|c|c|c|}
\hline \multirow[t]{2}{*}{ Complex } & \multicolumn{2}{|c|}{$\% \mathrm{C}$} & \multicolumn{2}{|c|}{$\% \mathrm{H}$} & \multicolumn{2}{|c|}{$\% \mathrm{~N}$} & \multicolumn{2}{|c|}{$\% \mathrm{Cu}$} \\
\hline & Found & Calculated & Found & Calculated & Found & Calculated & Found & Calculated \\
\hline$\left[\mathrm{CuL}_{2}\left(\mathrm{H}_{2} \mathrm{O}\right)_{2}\right]\left(\mathrm{NO}_{3}\right)_{2}$ & 61.27 & 61.84 & 4.83 & 4.42 & 10.67 & 10.31 & 7.59 & 7.73 \\
\hline
\end{tabular}

$\mathrm{L}=2,4,5$-triphenyl- $1 H$-imidazole 
The result of the elemental analysis on the precipitated complex are reported in Table 2. Calculated and found element percent are in good agreement. It can be noted that the complex do not have the external water molecules even if the experimental conditions previously reported were strictly followed. It can be due to the drying process that removes all the unstructured water molecules.

\section{Magnetic Moment Measurement}

The magnetic moment data of the solid complexes at room temperature showed that all complex are paramagnetic. The magnetic moment value of $\mathrm{Cu}$ (II) complex (1.96 BM) is higher than the theoretical spin only value of $\mathrm{Cu}$ (II) complex refers to spin orbital coupling. These values indicate octahedral structure for complex $\mathrm{Cu}$ (II).

\section{FT-IR}

The most important IR bands of 2,4,5triphenyl- $1 H$-imidazoles ligand with their assignments are presented in fig 2 . The ligand spectrum showed 3080, 1602, 1949 and 765 $\mathrm{cm}^{-1}$ attributed, respectively to $(\mathrm{CH}, \mathrm{C}=\mathrm{C}$, overtone aromatic, out of plane aromatic). Complex compounds [Cu(II)-2,4,5-triphenyl$1 \mathrm{H}$-imidazole $\left.\left(\mathrm{H}_{2} \mathrm{O}\right)_{2}\right]\left(\mathrm{NO}_{3}\right)_{2}$ measured at wave number $3000-500 \mathrm{~cm}^{-1}$. This spectrum is used to determine the presence of functional groups in a complex compound that can assist in predicting the structure of complex compounds. In FTIR spectra, peaks widened at wave number $1600-1700 \mathrm{~cm}^{-1}$ which indicates the presence of $\mathrm{C}-\mathrm{N}$ bonded to the metal $\mathrm{Cu}$ with coordination ligand 2,4,5-triphenyl- $1 \mathrm{H}$ - imidazole. Peak in the area of $3039.60 \mathrm{~cm}^{-1}$ is a $\mathrm{C}-\mathrm{H}$ bond stretching aromatic peak. In addition $1600-1700 \mathrm{~cm}^{-1}$ is a vibration of C-N ligand 2,4,5-triphenyl- $1 H$-imidazole with coordination $\mathrm{Cu}$ logam. $\mathrm{Cu}-\mathrm{N}$ bond is shown in wave numbers $422.38 \mathrm{~cm}^{-1}$. In the FTIR spectrum, $\mathrm{NO}_{3}$ bond of synthesized complex $[\mathrm{Cu}(\mathrm{II})-2,4,5$-triphenyl- $1 \mathrm{H}$ imidazole $]\left(\mathrm{NO}_{3}\right)_{2}$ appears at wave number $1400 \mathrm{~cm}^{-1}$. While the $\mathrm{Cu}-\mathrm{O}$ bond is observed at $534.25 \mathrm{~cm}^{-1}$ region.

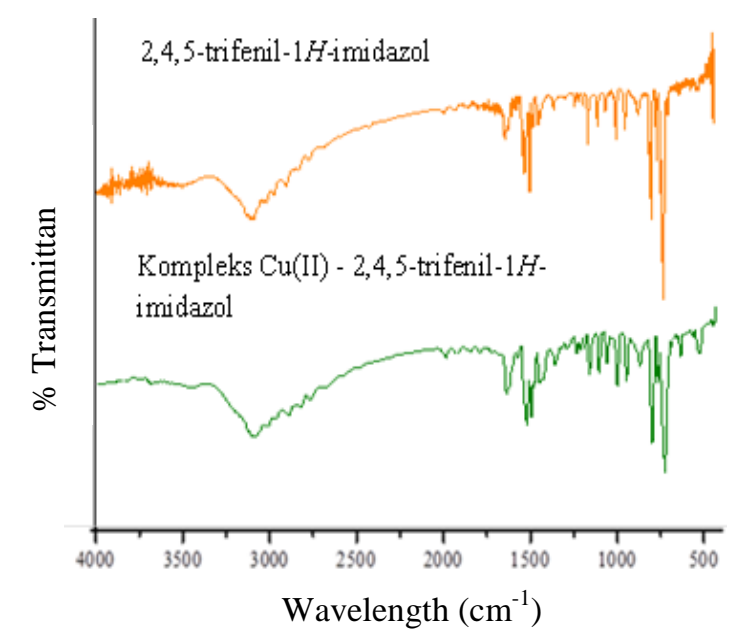

Fig 2. IR Spectra of the 2,4,5-triphenyl- $1 H$ imidazoles ligand and complex $\mathrm{Cu}(\mathrm{II})$ with 2,4,5-triphenyl-1H-imidazoles ligand

\section{NMR $\left({ }^{1} \mathrm{H}\right.$ and $\left.{ }^{13} \mathrm{C}\right)$ Spectra}

Its ${ }^{1} \mathrm{H}$ and ${ }^{13} \mathrm{C}$ NMR spectrum of $2,4,5$ triphenyl- $1 H$-imidazoles ligand was recorded in $\mathrm{d}^{6}$-DMSO reported in table 1 and showed in figure 3 for ${ }^{1} \mathrm{H}$ NMR figure 4 for ${ }^{13} \mathrm{C}$ NMR.

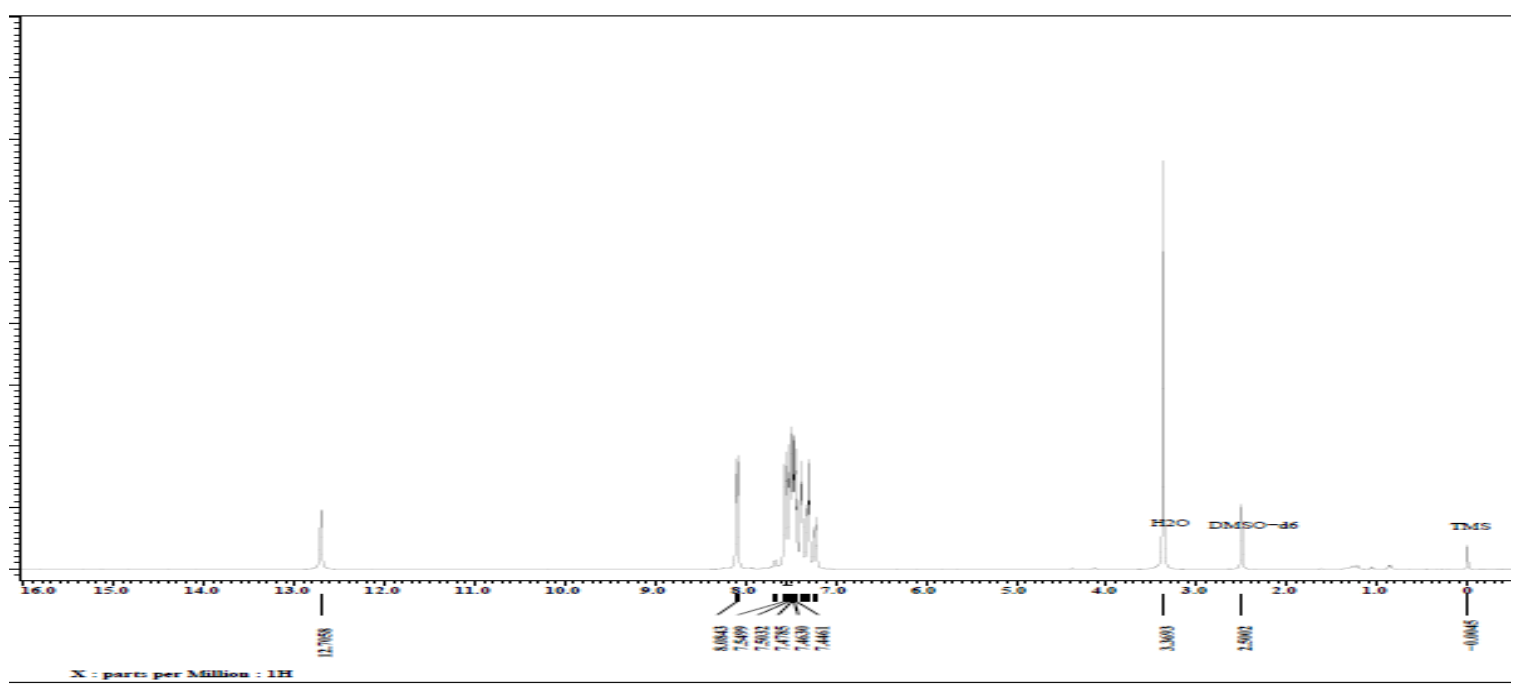

Figure 3. ${ }^{1} \mathrm{H}$ NMR of the 2,4,5-triphenyl-1H-imidazoles ligand 


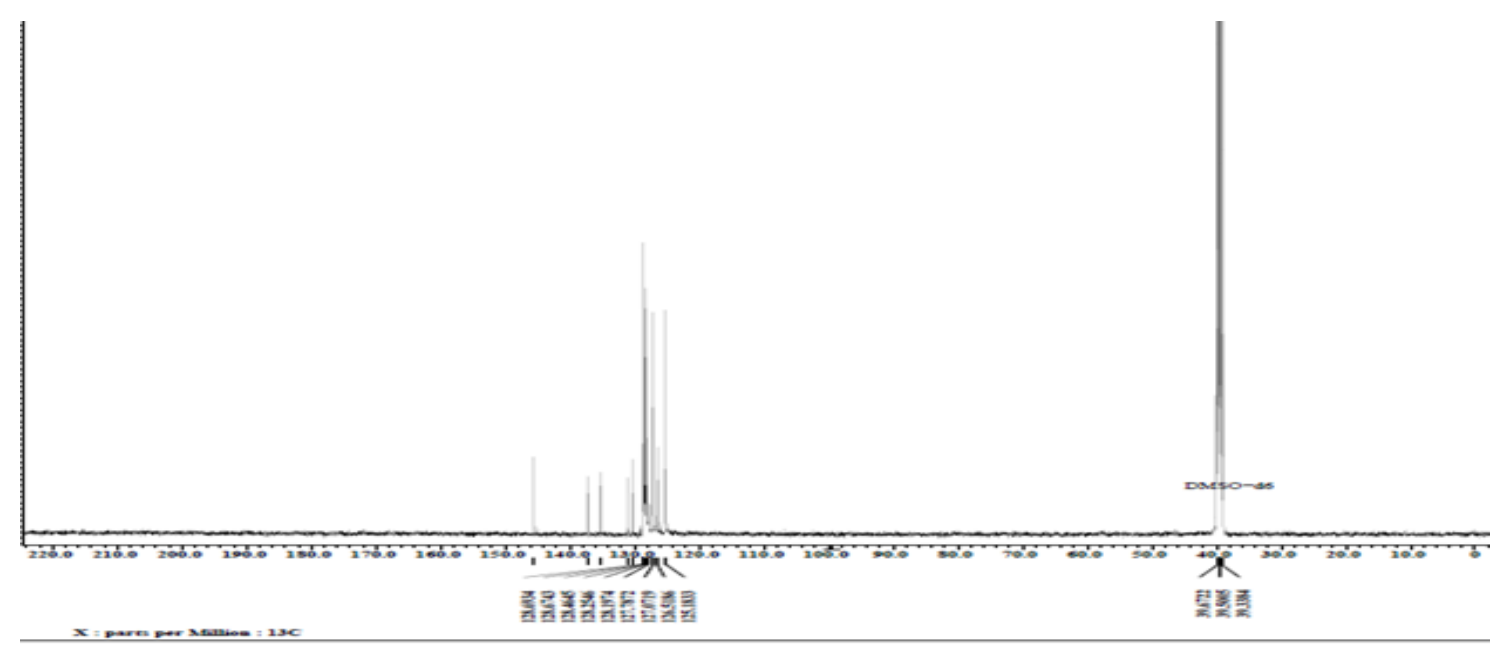

Figure 4. ${ }^{13} \mathrm{C}$ NMR of the 2,4,5-triphenyl-1 $H$-imidazoles ligand

Table 2. ${ }^{1} \mathrm{H}$ NMR and ${ }^{13} \mathrm{C}$ NMR data of the 2,4,5triphenyl- $H$-imidazoles ligand

\begin{tabular}{cc}
\hline${ }^{1} \mathbf{H}$ NMR $\boldsymbol{\delta}(\mathbf{p p m})$ & ${ }^{\mathbf{1 3}} \mathbf{C} \mathbf{N M R} \boldsymbol{\delta}(\mathbf{p p m})$ \\
\hline $12.70(\mathrm{~s}, 1 \mathrm{H}, \mathrm{NH})$ & $145.5 ; 137.1 ; 135.2 ;$ \\
$8.09-8.08(\mathrm{~d}, 2 \mathrm{H})$ & $131.1 ; 130.3 ; 128.7 ;$ \\
$7.56-7.55(\mathrm{~d})$ & $128.6 ; 128.5 ; 128.3 ;$ \\
$7.52-7.43(\mathrm{~m})$ & $128.2 ; 127.8 ; 127.1 ;$ \\
$7.31-7.36(\mathrm{t})$ & $126.5 ; 125.2$ \\
$7.32-7.29(\mathrm{t})$ & \\
$7.24-7.21(\mathrm{t})$ & \\
\hline
\end{tabular}

\section{Molar Conductance}

Table 3. Molar conductance of $\mathrm{Cu}$ (II) complex

\begin{tabular}{lcc}
\hline \multicolumn{1}{c}{ Compound } & $\begin{array}{c}\boldsymbol{\Lambda}_{\mathbf{m}} \\
\left(\mathbf{S . c m}^{\mathbf{2}} \cdot \mathbf{m o l}^{\mathbf{1}} \mathbf{)}\right.\end{array}$ & Electrolyte \\
\hline Methanol & 4.75 & - \\
$\mathrm{KCl}$ in methanol & 98.57 & $1: 1$ \\
$\mathrm{MgCl}_{2}$ in methanol & 157.45 & $2: 1$ \\
$\mathrm{FeCl}_{3}$ in methanol & 258.85 & $3: 1$ \\
$\begin{array}{l}\text { Complex } \mathrm{Cu}(\mathrm{II}) \text { in } \\
\text { methanol }\end{array}$ & 161.05 & $2: 1$ \\
\hline
\end{tabular}

\section{Thermogravimetry Analysis}

Thermogravimetric analysis was used to estimate species that decompose or left. It can be determined by comparing the weight of the sample at a temperature of decomposition to the initial weight. The results of analysis by Thermal Gravimetric Analyser (TGA) of complex compounds $\mathrm{Cu}$ (II) is shown in Figure 5. The analysis was performed with a heating rate of $10{ }^{\circ} \mathrm{C} / \mathrm{h}$ at $20-600{ }^{\circ} \mathrm{C}$ and the initial sample weight of $23.7 \mathrm{mg}$.

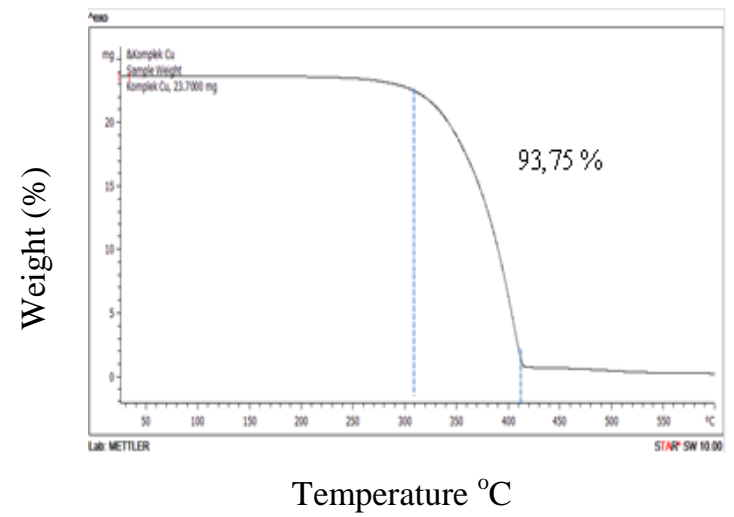

Figure 4. Thermogravimetry analysis of complex $\mathrm{Cu}$ (II) with 2,4,5-triphenyl- $1 H$ imidazole

Based on the results of this analysis, it can be seen that the decomposition does not happen at temperature $120-150{ }^{\circ} \mathrm{C}$ which indicates that the complex does not contain crystal water. Decomposition peak appeared at between $291.55-417.47^{\circ} \mathrm{C}$. At this temperature decomposition was as much as $93.75 \%$. At this temperature it was predicted that mass loss was metal, the two ligand 2,4,5-triphenyl- $1 \mathrm{H}$ imidazole, two water ligands, and $\mathrm{HNO}_{3}$ ligand. The predictions of complex compounds of formula $[\mathrm{Cu}$ (II)-2,4,5-triphenyl- $1 \mathrm{H}$ imidazole $\left.\left(\mathrm{H}_{2} \mathrm{O}\right)_{2}\right]\left(\mathrm{NO}_{3}\right)_{2}$.

\section{Toxicity Test}

Toxicity tests were performed using the BSLT (Brine Shrimp Lethality Test) 
method. Experimental animals used in this method is the larval of Artemiasalina shrimp. The $\mathrm{LC}_{50}$ values will be obtained from this test. This value is used to determine the toxicity of a compound. Toxicity tests were performed using the BSLT (Brine Shrimp Lethality Test) method (Meyer, 1982). In this test, variations in the concentration used is $25 \mathrm{ppm}, 50 \mathrm{ppm}$, $100 \mathrm{ppm}, 250 \mathrm{ppm}, 500 \mathrm{ppm}$ and $1000 \mathrm{ppm}$. The measurement was performed with three repetitions (triplo) for each concentration .Data on the number of deaths in each of various concentrations shown in Table 4. Then log concentration against \% mortality graph is shown in Figure 4.

Table $4 . \mathrm{LC}_{50}$ value with BSLT method

\begin{tabular}{ccccc}
\hline $\begin{array}{c}\text { Concentration } \\
\text { ppm }\end{array}$ & Log & Dead & Life & $\begin{array}{c}\text { \% } \\
\text { Mortality }\end{array}$ \\
\hline 25 & 1.40 & 0 & 31 & 0.00 \\
50 & 1.70 & 2 & 30 & 2.02 \\
100 & 2.00 & 6 & 25 & 10.67 \\
250 & 2.40 & 8 & 24 & 27.59 \\
500 & 2.70 & 12 & 18 & 60.87 \\
1000 & 3.00 & 31 & 0 & 100.00 \\
\hline
\end{tabular}

Through calculations using polynomial regression equation in Figure 5 , it is known that the $\mathrm{LC}_{50}$ values is $389.04 \mathrm{mg} / \mathrm{L}$ (complete calculation in appendix). $\mathrm{LC}_{50}$ value of the complex $\mathrm{Cu}$ (II)-2,4,5-triphenyl- $1 H$-imidazole proven research (Walia et al., 2011) that the more aromatic compounds in the complex can enhance the stability and biological activity. $\mathrm{LC}_{50}$ value obtained is greater than the value of the pure compound toxicity limit which is 200 ppm.

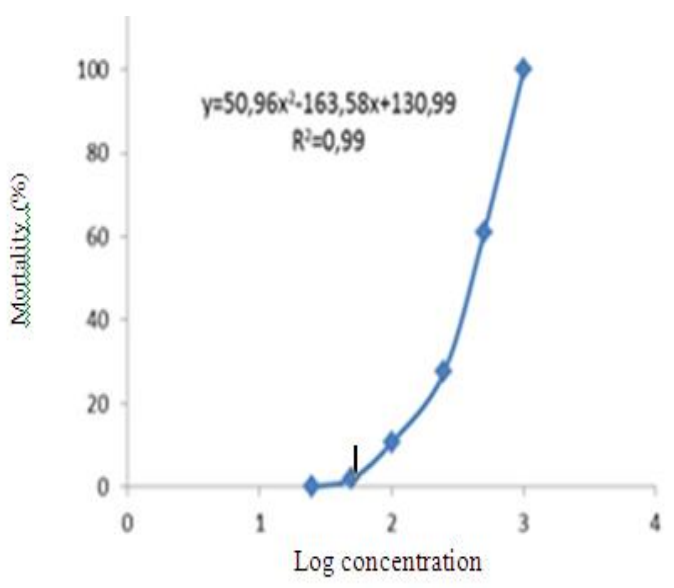

Figure 5. BSLT (Brine Shrimp Lethality Test)

\section{Anticancer Activity}

$\mathrm{Cu}$ (II) complex with 2,4,5-triphenyl$1 \mathrm{H}$-imidazole ligand has been sought for anticancer treatment. The values of $\mathrm{IC}_{50}$, compared with the standard drug doxorubicin (Drox) the liver Carninoma (HEPG2) are collected in Table 4. Untreated cells were used as a control. The ligand and $\mathrm{Cu}$ (II) complex showed an inhibition of cell viability and gave the $\mathrm{IC}_{50}$ value $8.7 \mu \mathrm{M}$ and $19.8 \mu \mathrm{M}$ against HEPG2, respectively, compared with $\mathrm{IC}_{50}$ value of $4.73 \mu \mathrm{M}$ for the standard cytotoxin drug doxorubicin.

\section{CONCLUSION}

A schiff base of 2,4,5-triphenyl- $1 H$ imidazole ligand and $\mathrm{Cu}$ (II) complexes were synthesized and characterized by ${ }^{1} \mathrm{H}$ and ${ }^{13} \mathrm{C}$ NMR, elemental analyses, molar conductance, thermal analysis (TGA), magnetic moment measurement, IR and UV-Vis. On the basis spectral studie and analytical data, it is evident that the Schiff base acts as monodentat ligand coordinating via nitrogen atom.. The $\mathrm{Cu}$ (II) complex have octahedral geometry. The kinetic and thermodynamic parameters of the thermal decomposition stages have been evaluated using Coats. Redfern method. In vitro anticancer activity of these complexes showed $\mathrm{IC}_{50} 19.8 \mu \mathrm{M}$.

\section{AKNOWLEDGEMENT}

The authors would like to acknowledge the Directorate of Higher Education, Ministry of Education and Culture of Indonesia for funding this research by scheme of Hibah Penelitian Kompetensi, no 01754/IT2.11/PN.09/2014 and Laboratory of Natural Product Chemistry and Synthesis, Department of Chemistry ITS for technical supports.

\section{REFERENCES}

Joshi RS, Mandhane PG, Shaikh MU, Kale RP, Gill $\mathrm{CH}$ Chin. 2010. Potassium dihydrogen phosphate catalyzed one-pot synthesis of 2,4,5-triaryl-1H-imidazoles. Chem. Lett. 21: 429-432.

Mohammadi A, Keshvari H, Sandaroos R, Rouhi H, Sepehr ZJ. 2012. A novel polymeric catalyst for the one-pot synthesis of 2,4,5- 
triaryl-1H-imidazoles. Chem. Sci. 124: 717-722.

Rahmapreet Walia MD. Heditullah Syeda Farha Naaz, Khalid Iqbal, HS Lamda. 2011. Benzoimidazole derivatives-a review. International Journal of Research in Pharmacy and Chemistry. 2231-2781

Sadler PJ. 1991. Advance Inorganic Chemistry. first ed.

Shelke KF, Sapkal SB, Shitole NV, Shingate BB, Shingare MS Bull. 2009. MicrowaveAssisted Synthesis of 3-Styrylchromones in Alkaline Ionic Liquid. Korean Chemical Soc. 30(12): 2883-2886.

Ucucu U, Karaburun NG, Isikdag I Farmaco. 2001. Ueber die einwirkung des ammoniaks auf glyoxal. European Journal of Organic Chemistry. 56: 285-290.

Wahyuningrum D. 2008. Sintesis Senyawa Turunan Imidazol dan Penentuan Aktivitas Inhibisi Korosinya pada Permukaan Baja
Karbon. Thesis, Institut Teknologi Bandung.

Walia Vijay. 2011. The cancer center genetics branch, National Human Genome Research Institute, National Institutes of Health (NIH), Bethesda, Maryland: USA

Wang L, Woods KW, Li Q, Barr KJ, McCroskey RW, Hannick SM, Gherke L, Credo RB, Hui YH, Marsh K, Warner R, Lee JY, Zielinsky-Mozng N, Frost D, Rosenberg SH, Sham HL, J otent, 2002. Orally active heterocycle-based combretastatin A-4 analogues: synthesis, structure-activity relationship, pharmacokinetics, and in vivo antitumor activity evaluation. Med. Chem. 45(8): 1697-1711.

Zala SP, Badmanaban R, Dhrubo JS, Chhaganbhai NP. 2012. Synthesis and biological evaluation of 2,4,5-triphenyl- $1 \mathrm{H}$ imidazole-1-yl Derivatives. Journal of Applied Pharmaceutical Science. 202-208. 